\title{
Effects of plant essential oil supplementation on growth performance, immune function and antioxidant activities in weaned pigs
}

\author{
Guoqi Su ${ }^{1 \dagger}$, Xuanwu Zhou ${ }^{1 \dagger}$, Yu Wang ${ }^{1}$, Daiwen Chen ${ }^{1}$, Guang Chen ${ }^{2}$, Yan Li ${ }^{2}$ and Jun He ${ }^{1 *}$
}

\begin{abstract}
Background: The aim of this study was to determine the effects of plant essential oil supplementation on growth performance, immune function and antioxidant activities in weaned pigs.

Methods: In the study, 24 weaned pigs were used to explore the effects of plant essential oil (PEO) on growth performance, immune properties and antioxidant activities. Pigs were fed with a basal diet (CON) or basal diet containing different concentrations of PEO (PEO50: 50 ppm; PEO100: 100 ppm; PEO200: 200 ppm). After 3 weeks, all pigs were slaughtered and blood and tissue samples were collected for biochemical analysis.

Results: The results showed that PEO supplementation quadratically increased body weight gain (BWG) $(P=0.031)$, linearly $(P<0.05)$ and quadratically $(P<0.05)$ decreased F:G. In addition, IgG increased linearly $(P<0.05)$ and $\lg M$ increased linearly $(P<0.05)$ and quadratically $(P<0.05)$ as PEO supplementation. Similarly, MDA in serum, jejunal mucosa and pancreas were linearly decreased $(P<0.05)$ and GSH in serum (linear and quadratic, $P<0.05)$, duodenal mucosa (linear and quadratic, $P<0.05$ ) and in ileal mucosa (linear and quadratic, $P<0.05$ ) were notably increased. Futhermore, antioxidant-related genes expression levels of GST in spleen (linear and quadratic, $P<0.05$ ), GPX1 (quadratic, $P<0.05$ ) and SOD1 (linear, $P<0.05$ ) in spleen and GST in liver (quadratic, $P<0.05$ ) were markedly upregulated by PEO supplementation increasing.
\end{abstract}

Conclusions: These results suggest that PEO improves growth performance, immune function, and antioxidant activities in weaned pigs, and it may also relieve weaning stress if used as a feed additive in the livestock industry. And that supplementation 200 ppm PEO in diet would seem to be economically feasible.

Keywords: Antioxidant activities, Growth performance, Immunity, Plant essential oil, Weaned pigs

\section{Background}

Recent studies have indicated that weaning can induce oxidative stress in pigs, resulting in oxidative damage [1]. Weaning stress has been reported to disrupt intestinal health, cause diarrhea, and to reduce growth and immunity in pigs [2-4]. Over the past number of decades, antibiotics, zinc oxide, and copper sulfate have been widely utilized in the swine industries for their effects in reducing diarrhea and improving immunity in weanling pigs [5-7]. However, the abuse of these additives has led to antibiotic resistance and heavy metal residues in livestock products.

\footnotetext{
* Correspondence: hejun8067@163.com

${ }^{\dagger}$ Guoqi Su and Xuanwu Zhou contributed equally to this work.

${ }^{1}$ Institute of Animal Nutrition, Sichuan Agricultural University, Chengdu,

Sichuan 611130, People's Republic of China

Full list of author information is available at the end of the article
}

The rising incidence of these serious problems has compelled research institutes and farmers alike to search for safe feed additives [8-10].

Many essential oils from plants, either extracted or in their natural form, are used for their antioxidative properties, which are mainly due to phenolic compounds in the oil or in other phytochemical fractions [11, 12]. Some nonphenolic substances also exhibit considerable antimicrobial and antioxidative potential [13, 14]. Previous studies have reported that essential oils may improve nutrient digestibility, as well as intestinal morphology and microflora [15-17]. Other studies have reported that essential oil supplementation improved the nutritional value and oxidative stability of fat, meat, and eggs, resulting in longer shelf-life [18-23]. These previous 
findings regarding animal products led us to hypothesize whether essential oils could improve systemic redox balance and reduce oxidative injury induced by weaning stress in young pigs.

Cinnamaldehyde is an organic compound with the formula $\mathrm{C}_{6} \mathrm{H}_{5} \mathrm{CH}=\mathrm{CHCHO}$, and thymol is a natural monoterpene phenol with the formula $\mathrm{C}_{10} \mathrm{H}_{14} \mathrm{O}$ (Fig. 1). Although several studies have indicated that cinnamaldehyde and thymol can improve growth performance, nutrient digestibility, and intestinal morphology, and stabilize the microflora of weaned pigs and poultry [11, 17, 24, 25], the effects of cinnamaldehyde and thymol on antioxidant activity and immune function in weaned pigs is still unclear. Therefore, the purpose of this study was to explore the effects of dietary supplementation with plant essential oil on both immune function and antioxidant activity in weaned pigs.

\section{Methods}

\section{Animals and experimental design}

A total of twenty-four commercial crossbred DLY (Duroc $\times$ Large White $\times$ Landrace) male pigs weaned at $35 \mathrm{~d}$ with average weight $9.19 \mathrm{~kg}$ (SEM 0.34) were randomly assigned to four groups $(n=6): 1) \mathrm{CON}$ (control; a basal diet), 2) PEO50 (basal diet containing $50 \mathrm{ppm}$ PEO), 3) PEO100 (basal diet containing 100 ppm PEO), 4) $\mathrm{PEO} 200$ (basal diet containing $200 \mathrm{ppm}$ PEO). PEO was provided by Cheng Du Hua Luo Bio-Tech Col. and the active ingredient of PEO was 13.5\% thymol and 4.5\% cinnamyl aldehyde, carrier was dextrin.

\section{Diets and feeding management}

Diets were corn-soybean based diets and formulated according to National Research Council 2012 requirements [26]. Ingredients and nutrient composition of experimental diets are shown in Table 1. Diets were fed in mash form throughout the experiment.

The experiment was carried out at the Research Base of the Institute of Animal Nutrition of Sichuan Agricultural University. All the pigs were housed in an environmentally controlled nursery room in individual metabolism cages $(1.5 \mathrm{~m} \times 0.7 \mathrm{~m} \times 1.0 \mathrm{~m})$. The pigs had free access to diet

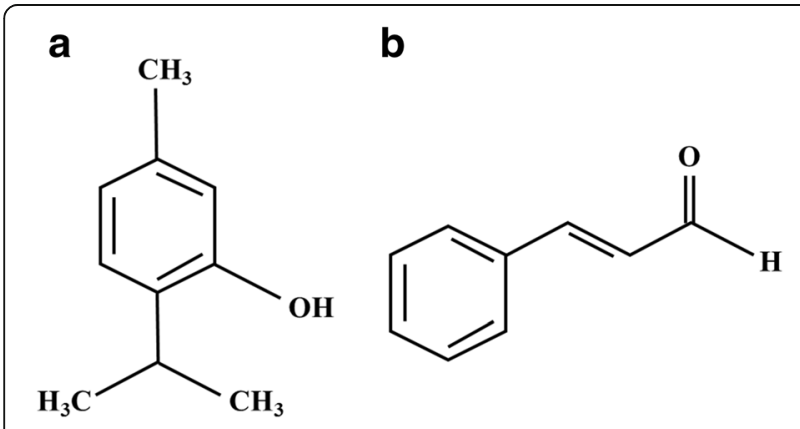

Fig. 1 Chemical structure of thymol (a) and cinnamaldehyde (b)
Table 1 Compositions and nutrient levels of the basal diet (air-dried basis) $^{\text {a }}$

\begin{tabular}{|c|c|c|c|}
\hline \multicolumn{2}{|l|}{ Composition } & \multicolumn{2}{|l|}{ Nutrient level } \\
\hline Ingredients & Proportion, $\%$ & Items & Cotent, $\%$ \\
\hline$\overline{\text { Maize }}$ & 30.00 & $\mathrm{CP}$ & 19.80 \\
\hline Extruded maize & 26.00 & $\mathrm{Ca}$ & 0.91 \\
\hline Soyabean meal, dehulled & 10.50 & Total P & 0.55 \\
\hline Puffed soyabean & 4.53 & P (available) & 0.37 \\
\hline Fishmeal & 4.90 & Lys & 1.41 \\
\hline Soya protein concentrate & 8.00 & Met & 0.47 \\
\hline Whey powder & 8.00 & Thr & 0.79 \\
\hline Glucose & 3.00 & Trp & 0.22 \\
\hline Soya oil & 2.50 & DE & 14.02 \\
\hline Calcium carbonate & 1.20 & & \\
\hline Calcium phosphate & 0.20 & & \\
\hline L-Lys HCl & 0.38 & & \\
\hline $\mathrm{NaCl}$ & 0.25 & & \\
\hline Choline chloride & 0.10 & & \\
\hline DL-Met & 0.15 & & \\
\hline Trp & 0.01 & & \\
\hline L-Thr & 0.03 & & \\
\hline Vitamins $^{b}$ & 0.05 & & \\
\hline Minerals ${ }^{c}$ & 0.20 & & \\
\hline
\end{tabular}

${ }^{a}$ Dietary nutrient level value was analyzed

'The vitamin and mineral premix (maize powder as diluent) provided the following amounts per kg complete diet: retinol, $8.4 \mathrm{mg}$; cholecalciferol, $0.008 \mathrm{mg}$; vitamin $\mathrm{E}$, $20 \mathrm{mg}$; menadione, $1 \mathrm{mg}$; vitamin B12, $0.03 \mathrm{mg}$; riboflavin, $5 \mathrm{mg}$; niacin, $20 \mathrm{mg}$; pantothenic acid, $15 \mathrm{mg}$; folic acid, $0.5 \mathrm{mg}$; thiamin, $1.5 \mathrm{mg}$; pyridoxine, $2 \mathrm{mg}$; biotin, $0.1 \mathrm{mg}$

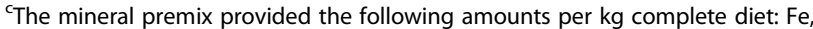
$100 \mathrm{mg}\left(\mathrm{FeSO}_{4} \cdot 7 \mathrm{H}_{2} \mathrm{O}\right) ; \mathrm{Cu}, 6 \mathrm{mg}\left(\mathrm{CuSO}_{4} \cdot 5 \mathrm{H}_{2} \mathrm{O}\right) ; \mathrm{Zn}, 100 \mathrm{mg}\left(\mathrm{ZnSO}_{4} \cdot 7 \mathrm{H}_{2} \mathrm{O}\right) ; \mathrm{Mn}$,

$4 \mathrm{mg}\left(\mathrm{MnSO}_{4} \cdot \mathrm{H}_{2} \mathrm{O}\right)$; $\mathrm{Se}, 0.3 \mathrm{mg}\left(\mathrm{Na}_{2} \mathrm{SeO}_{3} \cdot 5 \mathrm{H}_{2} \mathrm{O}\right) ; \mathrm{l}, 0.14 \mathrm{mg}(\mathrm{KI})$

and water throughout the 2-week feeding trial, and were fed with the experimental diets 4 times daily at 08:00, 12:00, 16:00 and 20:00. Temperature was gradually reduced from $28{ }^{\circ} \mathrm{C}$ to $23{ }^{\circ} \mathrm{C}$, and the humidity was controlled between 50 and $60 \%$. Pigs were weighed at 08:00 on an empty stomach on days 0 and 14 .

\section{Sample collection}

Blood samples were collected from the portal vein precava into Vacuum pick blood vessels without anticoagulation (Axygen Biotechnology Co. Ltd) at 8:00 in the morning on day 14. From each sample, serum were collected by centrifuging the blood $\left(3500 \mathrm{~g}, 4{ }^{\circ} \mathrm{C}, 10 \mathrm{~min}\right)$ and immediately stored at $-20{ }^{\circ} \mathrm{C}$. All pigs were slaughtered by exsanguination according to protocols approved by the Sichuan Agricultural University Animal Care Advisory Committee. Mucosa of duodenum, jejunum and ileum, spleen, liver and pancreas were collected and snap frozen in liquid $\mathrm{N}_{2}$ and then stored at $-80^{\circ} \mathrm{C}$ for assay. 


\section{Growth performance}

Individual initial and final body weight were recorded on day 0 and day 14. Body weight gain (BWG) was calculated as final body weight subtract initial body weight. Average daily gain (ADG) was calculated as weight $(\mathrm{kg}) /$ number of days from initial to final weight.

\section{Immunity parameters}

The levels of total protein (TP), albumin (ALB), IgG and IgM in serum were examined using the Hitachi 7020 Automatic Analyzer (Tokyo, Japan). The level of IgA in serum was measured using an ELISA test kit (R\&D Systems, Minneapolis, MN, USA) according to the manufacturer's instructions, the absorbance was determined with a 96-well microtiter plate reader Spectramax M2 (Molecular Devices, Sunnyvale, CA).

\section{Antioxidant indices in serum and tissues}

Tissues of duodenum, jejunum, ileum, spleen, liver and pancreas were homogenized $(1: 10, \quad w: v)$ in glass homogenizer with ice-cold $0.9 \%$ normal saline. Homogenate were collected by centrifuging $3500 \mathrm{~g}, 4{ }^{\circ} \mathrm{C}$, $15 \mathrm{~min}$. TP, glutathione (GSH), catalase (CAT), total antioxidant capacity (T-AOC), Malondialdehyde (MDA) and total superoxide dismutase (T-SOD) of serum and tissues were quantified by spectrophotometric methods using a spectrophotometer (Leng Guang SFZ1606017568, Shanghai, China).

\section{Total protein concentration analysis}

Total protein assay kit BCA (A045-3) was purchased from Nanjing Jiancheng Bioengineering Institute (Nanjing, China). Apple green BCA reacted with protein at $37{ }^{\circ} \mathrm{C}$ for $30 \mathrm{~min}$ and formed a purple compound featuring absorbance at $562 \mathrm{~nm}$. TP results are expressed as aprot per litre (gprot/L) of tissues.

\section{GSH content analysis}

GSH content was measured according to previous report. [4] Reduced GSH assay kit (A006-2, Nanjing Jiancheng Bioengineering Institute (Nanjing, China)) was used according manufacturer's instructions. GSH content was expressed in gGSH/L and mgGSH/gprot in serum and tissues respectively by using commercial GSH as a standard.

\section{CAT activity analysis}

CAT activity was measured according to previous report [27]. CAT assay kit (A007-1, Nanjing Jiancheng Bioengineering Institute (Nanjing, China)) was used according manufacturer's instructions. The reaction of CAT decomposing $\mathrm{H}_{2} \mathrm{O}_{2}$ was rapidly stopped reaction after adding ammonium molybdate. The rest of $\mathrm{H}_{2} \mathrm{O}_{2}$ reacted with ammonium molybdate and formed a pale yellow complex compound featuring absorbance at $405 \mathrm{~nm}$. CAT results were expressed in $\mathrm{U} / \mathrm{mL}$ and $\mathrm{U} /$ gprot in serum and tissues respectively.

\section{$T$-AOC activity analysis}

T-AOC activity was measured according to previous report [28]. Total antioxidant capacity assay kit (A015-1, Nanjing Jiancheng Bioengineering Institute (Nanjing, China)) was used according manufacturer's instructions. T-AOC activity was expressed in $\mathrm{U} / \mathrm{mL}$ and $\mathrm{U} /$ gprot in serum and tissues respectively.

\section{MDA content analysis}

MDA content was analyzed as described by previous report [29]. MDA assay kit (TBA method) (A003-1, Nanjing Jiancheng Bioengineering Institute (Nanjing, China)) was used according manufacturer's instructions. MDA reacted with thiobarbituric acid (TBA) formed a red-complex compound featuring absorbance at $532 \mathrm{~nm}$. MDA results were expressed in $\mathrm{nmol} / \mathrm{mL}$ in serum and tissues.

\section{T-SOD activity analysis}

T-SOD activity was analyzed as described by previous report [30]. Total Superoxide Dismutase (T-SOD) assay kit (Hydroxylamine method) (A001-1, Nanjing Jiancheng Bioengineering Institute (Nanjing, China)) was used according manufacturer's instructions. Superoxide ions reacted with 2-(4-iodophenyl)-3- (4-nitrophenol)-5-phenyltetrazolium chloride to form a red formazan dye featuring absorbance at $550 \mathrm{~nm}$. T-SOD activity was expressed in $\mathrm{U} / \mathrm{mL}$ in serum and tissues.

\section{RNA isolation and real-time quantitative PCR}

Total RNA from samples of spleen, liver and pancreas was extracted using TRIzol reagent (TaKaRa, Dalian, China) according to the manufacturer's instructions. RNA concentration was measured by Nanodrop 2000 (Thermo Fisher Scientific, Wilmington,DE, USA). The integrity of RNA was verified by eletrophoretic analysis. Complementary DNA (cDNA) was achieved by reverse transcription with $2 \mu$ g RNA sample using the PrimeScript ${ }^{\text {tm }}$ RT reagent Kit (TaKaRa, Dalian, China) according to the manufacturer's instructions. $20 \mu \mathrm{L}$ final reaction volume of cDNA was then diluted to $250 \mu \mathrm{L}$ using nuclease-free water and stored at $-20{ }^{\circ} \mathrm{C}$. The cDNA was used as the template for PCR. Real-time quantitative PCR was performed on cDNA using the ABI PRISM 7500 Fast Sequence Detection System for ninety-sixwell plates (Applied Biosystems). The primers of $\beta$-actin, superoxide dismutase 1 (SOD1), $C A T$, glutathione peroxidase 1 (GPX1), glutathione transferase $(G S T)$, glutathione reductase $(G R)$, nuclear factor E2-related factor 2 ( $N r f 2)$, Kelch-like ECH-associated protein 1 (Keap-1) are shown in Table 2 . The gene $\beta$-actin 
was used as an internal control. All the genes of each sample were repeated in triplicate. For each reaction, $5 \mu \mathrm{L}$ of freshly SYBR ${ }^{\odot}$ Premix Ex Taq ${ }^{\text {Tix }}$ II (Tli RNaseH Plus, 2×), $1 \mu \mathrm{L}$ forward primers $(4 \mathrm{mmol} / \mathrm{L})$ and $1 \mu \mathrm{L}$ reverse primers $(4 \mathrm{mmol} / \mathrm{L}), 1 \mu \mathrm{L}$ of $\mathrm{cDNA}$ and $2 \mu \mathrm{L}$ nuclease-free water were added and made up to final volume of $10 \mu \mathrm{L}$. The PCR programme was as follow: a predegeneration at $95{ }^{\circ} \mathrm{C}$ for $10 \mathrm{~min}$ for one cycle, followed by denaturation at $95{ }^{\circ} \mathrm{C}$ for $5 \mathrm{~s}$, annealing temperature at $60{ }^{\circ} \mathrm{C}$ for $45 \mathrm{~s}$, extension temperature at $72{ }^{\circ} \mathrm{C}$ for $10 \mathrm{~s}$ for forty cycles. After amplification, the melting peaks of the amplification products were determined by melting curve which indicated only one expected amplification products had been generated. Melting curve conditions were as follows: 1 cycle of denaturation at $95{ }^{\circ} \mathrm{C}$ for $10 \mathrm{~s}$ and then $65{ }^{\circ} \mathrm{C}$ changed to $95{ }^{\circ} \mathrm{C}$ with a temperature change velocity of $0.5^{\circ} \mathrm{C} / \mathrm{s}$. The standard curve of each gene was run in triplicate for obtaining reliable amplification efficiency values. The correlation coefficients of all the standard curves were $>0.99$, and the amplification efficiency values were between 90 and $110 \%$. Each primer pair used yielded a single peak in the melting curve and a single band with the expected size in agarose gel. The mean $\mathrm{Ct}$ values of duplicates of each sample were used for calculations. The relative gene expressions compared with the housekeeping gene b-actin were calculated by $2^{-\mathrm{CT}}$ [31].

\section{Statistical analysis}

All data were analysed using SPSS 20.0 software (SPSS, Inc.) by curve estimation model of regression procedure.
The effect of PEO supplementation was determined by linear and quadratic effects in individual pig unit. All data were expressed as mean \pm standard error. The significance level for all analyses was set at $P<0.05$, with a trend of $0.05 \leq P \leq 0.01$.

\section{Results}

Effect of PEO on growth performance

As indicated in Table 3, the BWG increased quadratically $(P=0.031)$, PEO200 increased the BWG $0.52 \mathrm{~kg}$ than CON. In addition, F:G also decreased linearly $(P=0.008)$ and quadratically $(P=0.007)$ as supplementation of PEO increased. PEO200 decreased 0.13 than CON in F: G.

\section{Effect of PEO on blood biochemical parameters and serum immunoglobulins}

The effect of PEO supplementation on the level of serum TP, ALB, IgG, IgA and IgM were presented in Table 4 . IgG increased linearly $(P=0.029)$ and IgM increased linearly $(P=0.003)$ and quadratically $(P=0.007)$ as supplementation of PEO increased. And then, supplementation of PEO tended quadratically $(P=0.098)$ increase IgM and linearly $(P=0.098)$ and quadratically $(P=0.070)$ increase ALB. Moreover, serum cholesterol was linearly $(P=0.039)$ as PEO supplementation.

\section{Effect of PEO on serum antioxidant activity}

There was a significant increase in serum GSH with increasing levels of PEO (linear, $P<0.01$; quadratic,

Table 2 Primers sequences used for quantitative RT-PCR ${ }^{a}$

\begin{tabular}{|c|c|c|c|}
\hline Gene & Accession no. & Primer sequences $\left(5^{\prime}-3^{\prime}\right)$ & $\begin{array}{l}\text { Product } \\
\text { Length, bp }\end{array}$ \\
\hline \multirow[t]{2}{*}{$\beta$-actin } & U07786.1 & F:TCTGGCACCACACCTTCT & 114 \\
\hline & & R:TGATCTGGGTCATCTTCTCAC & \\
\hline \multirow[t]{2}{*}{ SOD1 } & AF396674.1 & GATCAAGAGAGGCACGTTGGA & 62 \\
\hline & & GTGGCCACACCATCTITGC & \\
\hline \multirow[t]{2}{*}{ CAT } & NM_214 & GGACGTGCAGCGCTTCA & 52 \\
\hline & & CCGCACCTGGGTGACATTA & \\
\hline \multirow[t]{2}{*}{ GPX1 } & NM_214201.1 & GGCGGCGGGTTCGA & 55 \\
\hline & & CGCCATTCACCTCACACTTCT & \\
\hline \multirow[t]{2}{*}{ GST } & Z69586.1 & TCCCCACGGTGAAGAAGTTT & 57 \\
\hline & & CGTCAGTGGGAGGCTTCCT & \\
\hline \multirow[t]{2}{*}{$G R$} & AY368271.1 & CAGTAGAGGTCAACGGGAAGAAGT & 59 \\
\hline & & GCCGCCTGTGGCAATC & \\
\hline \multirow[t]{2}{*}{ Nrf2 } & XM_003133500.5 & GCCCCTGGAAGCGTTAAAC & 67 \\
\hline & & GGACTGTATCCCCAGAAGGTTGT & \\
\hline \multirow[t]{2}{*}{ Keap-1 } & NM_001114671.1 & ACGACGTGGAGACAGAAACGT & 56 \\
\hline & & GCTTCGCCGATGCTTCA & \\
\hline
\end{tabular}

${ }^{a} S O D 1$, superoxide dismutase 1; CAT, catalase; GPX1, glutathione peroxidase 1; GST, glutathione transferase; GR, glutathione reductase; Nrf2, nuclear factor E2-related factor 2; Keap-1, Kelch-like ECH-associated protein 1 
Table 3 Growth performance of weaned pigs fed different levels of PEO

\begin{tabular}{|c|c|c|c|c|c|c|}
\hline \multirow[t]{2}{*}{ Items $^{b}$} & \multirow[t]{2}{*}{$\mathrm{CON}$} & \multirow[t]{2}{*}{ PEO50 } & \multirow[t]{2}{*}{ PEO100 } & \multirow[t]{2}{*}{ PEO200 } & \multicolumn{2}{|l|}{ P } \\
\hline & & & & & Linear & Quadratic \\
\hline IBW & $9.25 \pm 0.41$ & $9.18 \pm 0.24$ & $9.16 \pm 0.61$ & $9.17 \pm 0.49$ & 0.977 & 0.294 \\
\hline FBW & $15.53 \pm 0.28$ & $15.52 \pm 0.20$ & $15.55 \pm 0.76$ & $16.00 \pm 0.54$ & 0.922 & 0.895 \\
\hline BWG, kg & $6.41 \pm 0.55$ & $6.33 \pm 0.23$ & $6.39 \pm 0.71$ & $6.83 \pm 0.33$ & 0.657 & 0.031 \\
\hline $\mathrm{ADG}, \mathrm{kg} / \mathrm{d}$ & $0.45 \pm 0.04$ & $0.45 \pm 0.02$ & $0.46 \pm 0.05$ & $0.50 \pm 0.03$ & 0.114 & 0.099 \\
\hline $\mathrm{ADFl}, \mathrm{kg} / \mathrm{d}$ & $0.67 \pm 0.07$ & $0.70 \pm 0.03$ & $0.67 \pm 0.19$ & $0.66 \pm 0.04$ & 0.770 & 0.829 \\
\hline$F: G$ & $1.47 \pm 0.05$ & $1.55 \pm 0.07$ & $1.43 \pm 0.38$ & $1.34 \pm 0.09$ & 0.008 & 0.007 \\
\hline
\end{tabular}

Treatments: CON means basal diet; PEO50 means basal diet with 50 ppm PEO; PEO100 means basal diet with 100 ppm PEO; PEO200 means basal diet with 200 ppm PEO ${ }^{a}$ Values are means $\pm S . E, n=6$

b IBW initial body weight, FBW final body weight, BWG body weight gain, $A D G$ average daily gain

$P<0.01$ ) (Table 5). Serum MDA increased linearly $(P=0.030)$ as supplementation of PEO increased.

\section{Effect of PEO on intestinal mucosal antioxidant activity} The effect of PEO supplementation on the level of intestinal mucosa TP, GSH, T-AOC, T-SOD, MDA and CAT were presented in Table 6. There was a significant increase in GSH with increasing levels of PEO in duodenal mucosa (linear, $P=0.007$; quadratic, $P=0.029$ ) and in ileal mucosa (linear, $P=0.011$; quadratic, $P=0.032$ ). MDA in jejunal mucosa decreased linearly $(P=0.042)$ as supplementation of PEO increased.

\section{Effect of PEO on splenic, hepatic and pancreatic antioxidant activity}

The levels of GSH, CAT, T-AOC, T-SOD and MDA in spleen, liver and pancreas were measured (Table 7). GSH in pancreas increased linearly $(P=0.007)$ and quadratically $(P=0.032)$ as supplementation of PEO increased. There was a decrease at $100 \mathrm{ppm}$ (linear, $P=0.032$ ) in MDA of pancreas with no further decrease at $200 \mathrm{ppm}$.
Effect of PEO on the expression of critical antioxidantrelated genes

Gene expression of GR, GST, GPX1, CAT, SOD1, Nrf1 and Keap 1 was measured (Table 8). Expression of GST in spleen increased linearly $(P=0.012)$ and quadratically $(P=0.007)$ as supplementation of PEO increased. There was a tendency to increase expression level of Keap 1 with increasing levels of PEO in spleen (quadratic, $P=0.085$ ). An increased in GPX1 (quadratic, $P=0.029$ ), $C A T$ (quadratic, $P=0.051$ ) and SOD1 (linear, $P=0.029$ ) was observed in the spleen of pigs supplemented with $200 \mathrm{ppm}$ PEO. Moreover, the expression of GST in liver increased quadratically $(P=0.049)$ as supplementation of PEO increased. However, the expression of Nrf2 in liver decreased linearly $(P=0.023)$ and quadratically $(P=0.029)$ as supplementation of PEO increased. Furthermore, there was no effect on the expression of GR, GST, GPX1, CAT, $S O D 1, N r f 1$ and Keap 1 in pancreas with increasing dietary inclusion level of PEO.

\section{Discussion}

Weaning stress syndrome was an inevitable problem, which could lead weaning stress, oxidative stress, and

Table 4 immune function of weaned pigs fed different levels of PEO

\begin{tabular}{|c|c|c|c|c|c|c|}
\hline \multirow[t]{2}{*}{ Items $^{\mathrm{b}}$} & \multirow[t]{2}{*}{ CON } & \multirow[t]{2}{*}{ PEO50 } & \multirow[t]{2}{*}{ PEO100 } & \multirow[t]{2}{*}{ PEO200 } & \multicolumn{2}{|l|}{$P$} \\
\hline & & & & & Linear & Quadratic \\
\hline $\mathrm{TP}, \mathrm{g} / \mathrm{L}$ & $50.03 \pm 1.69$ & $50.66 \pm 0.47$ & $51.89 \pm 0.64$ & $51.91 \pm 1.08$ & 0.235 & 0.489 \\
\hline ALB, g/L & $29.32 \pm 0.82$ & $28.98 \pm 0.39$ & $29.09 \pm 0.35$ & $30.90 \pm 0.43$ & 0.098 & 0.070 \\
\hline TG mmol/L & $0.58 \pm 0.06$ & $0.44 \pm 0.01$ & $0.44 \pm 0.07$ & $0.43 \pm 0.03$ & 0.346 & 0.171 \\
\hline TC mmol/L & $2.10 \pm 0.04$ & $2.29 \pm 0.06$ & $2.14 \pm 0.06$ & $1.95 \pm 0.06$ & 0.039 & 0.103 \\
\hline $\operatorname{lgG}, \mathrm{g} / \mathrm{L}$ & $2.55 \pm 0.25$ & $2.42 \pm 0.19$ & $3.31 \pm 0.43$ & $3.84 \pm 0.61$ & 0.003 & 0.007 \\
\hline $\lg A, g / L$ & $0.89 \pm 0.05$ & $0.89 \pm 0.08$ & $1.07 \pm 0.08$ & $1.14 \pm 0.07$ & 0.813 & 0.840 \\
\hline $\lg M, g / L$ & $0.23 \pm 0.03$ & $0.25 \pm 0.01$ & $0.25 \pm 0.02$ & $0.23 \pm 0.03$ & 0.029 & 0.098 \\
\hline
\end{tabular}

Treatments: CON means basal diet; PEO50 means basal diet with 50 ppm PEO; PEO100 means basal diet with 100 ppm PEO; PEO200 means basal diet with 200 ppm PEO

a Values are means \pm S.E, $\mathrm{n}=6$

${ }^{\mathrm{b}} T P$ total protein, $A L B$ albumin, $T G$ triglyceride, $T C$ cholesterol 
Table 5 Antioxidant in serum of weaned pigs fed different levels of PEO

\begin{tabular}{|c|c|c|c|c|c|c|}
\hline \multirow[t]{2}{*}{ Items $^{b}$} & \multirow[t]{2}{*}{ CON } & \multirow[t]{2}{*}{ PEO50 } & \multirow[t]{2}{*}{ PEO100 } & \multirow[t]{2}{*}{ PEO200 } & \multicolumn{2}{|l|}{ P } \\
\hline & & & & & Linear & Quadratic \\
\hline CAT, U/mL & $18.89 \pm 1.26$ & $19.62 \pm 1.22$ & $20.22 \pm 0.52$ & $20.18 \pm 0.53$ & 0.248 & 0.456 \\
\hline T-AOC, U/mL & $2.10 \pm 0.10$ & $2.13 \pm 0.12$ & $2.16 \pm 0.24$ & $2.32 \pm 0.13$ & 0.451 & 0.642 \\
\hline $\mathrm{MDA}, \mathrm{nmol} / \mathrm{mL}$ & $3.68 \pm 0.40$ & $3.21 \pm 0.24$ & $3.08 \pm 0.47$ & $2.67 \pm 0.28$ & 0.030 & 0.100 \\
\hline T-SOD, U/mL & $18.15 \pm 0.37$ & $18.34 \pm 0.18$ & $18.67 \pm 0.42$ & $18.27 \pm 0.13$ & 0.721 & 0.388 \\
\hline GSH, mgGSH/L & $3.12 \pm 0.58$ & $2.94 \pm 0.38$ & $3.98 \pm 0.56$ & $4.44 \pm 0.39$ & $<0.01$ & $<0.01$ \\
\hline
\end{tabular}

total superoxide dismutase; GSH, glutathione

Treatments: CON means basal diet; PEO50 means basal diet with 50 ppm PEO; PEO100 means basal diet with 100 ppm PEO; PEO200 means basal diet with 200 ppm PEO

${ }^{a}$ Values are means \pm S.E, $n=6$

${ }^{b} C A T$ catalase, $T-A O C$ total antioxidant capacity, MDA methane dicarboxylic aldehyde, $T$-SOD Total superoxide dismutase

adversely affects intestinal health, leads to diarrhea, and reduces growth and immunity in pigs [2-4]. Oxidative stress is caused by excess oxidative radicals, including reactive oxygen species, which damage DNA, bio-membrane lipids, and proteins, and also impair tissue function $[32,33]$. This may be the reason that weaning stress syndrome reduces growth performance and economic benefit in pig production. Thymol and cinnamaldehyde are concentrated hydrophobic liquids containing volatile aromatic compounds extracted from plants, which have unique chemical structures (Fig. 1) and could be used as natural antioxidants [11, 34].

In this study, dietary supplementation of PEO at a dose of 200 ppm quadratically improved BWG of pigs after weaning. As well as, ADG tended to increase quadratically as 200 ppm PEO supplementation increased. Because of there was no effect on average daily feed intake (ADFI) with the increasing PEO addition. So the most important reason for growth performance improvement was feed efficiency. F:G decreased linearly

Table 6 Antioxidant in intestinal mucosa of weaned pigs fed different levels of PEOa

\begin{tabular}{|c|c|c|c|c|c|c|}
\hline \multirow[t]{2}{*}{ Items $^{b}$} & \multirow[t]{2}{*}{ CON } & \multirow[t]{2}{*}{ PEO50 } & \multirow[t]{2}{*}{ PEO100 } & \multirow[t]{2}{*}{ PEO200 } & \multicolumn{2}{|l|}{$P$} \\
\hline & & & & & Linear & Quadratic \\
\hline \multicolumn{7}{|l|}{ Duodenal mucosa } \\
\hline TP, gprot/L & $77.09 \pm 7.06$ & $78.38 \pm 11.38$ & $78.30 \pm 6.59$ & $76.29 \pm 11.63$ & 0.960 & 0.981 \\
\hline GSH, mgGSH/gprot & $5.22 \pm 0.93$ & $5.73 \pm 1.35$ & $10.97 \pm 0.80$ & $12.02 \pm 2.30$ & 0.007 & 0.029 \\
\hline T-AOC, U/mgprot & $0.21 \pm 0.06$ & $0.23 \pm 0.02$ & $0.28 \pm 0.02$ & $0.27 \pm 0.01$ & 0.157 & 0.369 \\
\hline T-SOD, U/mL & $24.37 \pm 1.83$ & $24.79 \pm 3.97$ & $24.08 \pm 1.71$ & $24.90 \pm 0.31$ & 0.921 & 0.992 \\
\hline $\mathrm{MDA}, \mathrm{nmol} / \mathrm{mL}$ & $36.93 \pm 4.50$ & $26.64 \pm 4.24$ & $24.62 \pm 6.15$ & $19.37 \pm 6.43$ & 0.166 & 0.397 \\
\hline CAT, U/gprot & $16.32 \pm 2.15$ & $17.73 \pm 0.71$ & $17.78 \pm 1.83$ & $18.55 \pm 2.72$ & 0.380 & 0.676 \\
\hline \multicolumn{7}{|l|}{ Jejunal mucosa } \\
\hline TP, gprot/L & $83.91 \pm 10.41$ & $85.10 \pm 10.95$ & $83.61 \pm 10.58$ & $84.48 \pm 10.08$ & 0.992 & 1.000 \\
\hline GSH, mgGSH/gprot & $1.95 \pm 0.47$ & $2.48 \pm 1.29$ & $3.87 \pm 1.35$ & $2.80 \pm 0.84$ & 0.562 & 0.121 \\
\hline T-AOC, U/mgprot & $0.23 \pm 0.03$ & $0.27 \pm 0.01$ & $0.28 \pm 0.06$ & $0.27 \pm 0.07$ & 0.381 & 0.600 \\
\hline T-SOD, U/mL & $13.95 \pm 0.97$ & $16.16 \pm 1.79$ & $19.14 \pm 3.02$ & $20.12 \pm 2.22$ & 0.069 & 0.199 \\
\hline $\mathrm{MDA}, \mathrm{nmol} / \mathrm{mL}$ & $37.60 \pm 12.01$ & $33.60 \pm 3.27$ & $32.90 \pm 8.40$ & $14.00 \pm 2.79$ & 0.042 & 0.076 \\
\hline CAT, U/gprot & $4.63 \pm 0.83$ & $5.05 \pm 0.39$ & $5.35 \pm 0.32$ & $6.13 \pm 1.13$ & 0.254 & 0.528 \\
\hline \multicolumn{7}{|l|}{ lleal mucosa } \\
\hline TP, gprot/L & $138.13 \pm 6.15$ & $160.16 \pm 9.18$ & $131.34 \pm 10.15$ & $149.74 \pm 16.24$ & 0.974 & 0.999 \\
\hline GSH, mgGSH/gprot & $1.15 \pm 0.11$ & $1.98 \pm 0.26$ & $2.01 \pm 0.29$ & $2.35 \pm 0.16$ & 0.011 & 0.032 \\
\hline T-AOC, U/mgprot & $0.14 \pm 0.01$ & $0.18 \pm 0.03$ & $0.19 \pm 0.02$ & $0.19 \pm 0.03$ & 0.126 & 0.210 \\
\hline T-SOD, U/mL & $9.16 \pm 0.80$ & $9.11 \pm 0.44$ & $9.66 \pm 0.17$ & $9.68 \pm 0.55$ & 0.509 & 0.812 \\
\hline $\mathrm{MDA}, \mathrm{nmol} / \mathrm{mL}$ & $91.41 \pm 6.66$ & $87.18 \pm 13.15$ & $83.04 \pm 3.93$ & $71.57 \pm 4.29$ & 0.246 & 0.506 \\
\hline CAT, U/gprot & $5.36 \pm 0.31$ & $5.25 \pm 0.83$ & $6.64 \pm 0.73$ & $7.46 \pm 1.03$ & 0.114 & 0.279 \\
\hline
\end{tabular}

Treatments: CON means basal diet; PEO50 means basal diet with 50 ppm PEO; PEO100 means basal diet with 100 ppm PEO; PEO200 means basal diet with 200 ppm PEO avalues are means \pm S.E, $n=6$

${ }^{\mathrm{b}} T P$ total protein, GSH glutathione, CAT catalase, T-AOC total antioxidant capacity, MDA methane dicarboxylic aldehyde, $T$-SOD total superoxide dismutase 
Table 7 Antioxidant in spleen, liver and pancreas of pigs fed different levels of PEO

\begin{tabular}{|c|c|c|c|c|c|c|}
\hline \multirow[t]{2}{*}{ Items $^{b}$} & \multirow[t]{2}{*}{ CON } & \multirow[t]{2}{*}{ PEO50 } & \multirow[t]{2}{*}{ PEO100 } & \multirow[t]{2}{*}{ PEO200 } & \multicolumn{2}{|l|}{$P$} \\
\hline & & & & & Linear & Quadratic \\
\hline \multicolumn{7}{|l|}{ Spleen } \\
\hline GSH, mgGSH/gprot & $1.85 \pm 0.51$ & $1.65 \pm 0.24$ & $1.88 \pm 0.04$ & $2.19 \pm 0.15$ & 0.431 & 0.546 \\
\hline CAT, U/gprot & $9.87 \pm 0.71$ & $9.33 \pm 1.13$ & $11.34 \pm 0.68$ & $10.49 \pm 1.08$ & 0.334 & 0.635 \\
\hline T-AOC, U/mgprot & $0.21 \pm 0.04$ & $0.21 \pm 0.05$ & $0.22 \pm 0.02$ & $0.22 \pm 0.02$ & 0.812 & 0.963 \\
\hline $\mathrm{T}-\mathrm{SOD}, \mathrm{U} / \mathrm{mL}$ & $255.62 \pm 10.52$ & $247.22 \pm 26.99$ & $302.45 \pm 8.38$ & $291.02 \pm 9.06$ & 0.076 & 0.219 \\
\hline $\mathrm{MDA}, \mathrm{nmol} / \mathrm{mL}$ & $146.00 \pm 8.86$ & $175.07 \pm 26.70$ & $128.41 \pm 5.08$ & $117.84 \pm 7.44$ & 0.132 & 0.190 \\
\hline \multicolumn{7}{|l|}{ Liver } \\
\hline GSH, mgGSH/gprot & $1.84 \pm 0.30$ & $1.35 \pm 0.10$ & $2.59 \pm 0.30$ & $2.53 \pm 0.48$ & 0.113 & 0.256 \\
\hline CAT, U/gprot & $200.89 \pm 19.50$ & $204.58 \pm 6.33$ & $210.14 \pm 19.42$ & $206.30 \pm 12.45$ & 0.788 & 0.949 \\
\hline T-AOC, U/mgprot & $0.52 \pm 0.06$ & $0.43 \pm 0.11$ & $0.49 \pm 0.08$ & $0.55 \pm 0.13$ & 0.489 & 0.238 \\
\hline T-SOD, U/mL & $1127.18 \pm 59.43$ & $1132.51 \pm 58.80$ & $1161.75 \pm 97.09$ & $1200.82 \pm 99.96$ & 0.562 & 0.837 \\
\hline $\mathrm{MDA}, \mathrm{nmol} / \mathrm{mL}$ & $273.32 \pm 29.23$ & $280.04 \pm 26.55$ & $266.00 \pm 60.44$ & $263.64 \pm 21.62$ & 0.835 & 0.974 \\
\hline \multicolumn{7}{|l|}{ Pancreas } \\
\hline GSH, mgGSH/gprot & $2.23 \pm 0.30$ & $2.41 \pm 0.43$ & $4.47 \pm 0.66$ & $4.52 \pm 1.08$ & 0.007 & 0.032 \\
\hline CAT, U/gprot & $4.99 \pm 0.79$ & $5.14 \pm 0.39$ & $5.22 \pm 0.12$ & $6.40 \pm 0.81$ & 0.230 & 0.404 \\
\hline T-AOC, U/mgprot & $0.14 \pm 0.02$ & $0.12 \pm 0.02$ & $0.13 \pm 0.03$ & $0.14 \pm 0.01$ & 0.906 & 0.804 \\
\hline T-SOD, U/mL & $232.93 \pm 16.47$ & $207.09 \pm 12.92$ & $276.46 \pm 25.64$ & $257.91 \pm 9.82$ & 0.131 & 0.299 \\
\hline $\mathrm{MDA}, \mathrm{nmol} / \mathrm{mL}$ & $45.52 \pm 1.12$ & $61.65 \pm 9.02$ & $28.64 \pm 5.58$ & $29.96 \pm 3.40$ & 0.032 & 0.068 \\
\hline
\end{tabular}

aldehyde; T-SOD, total superoxide dismutase

Treatments: CON means basal diet; PEO50 means basal diet with 50 ppm PEO; PEO100 means basal diet with 100 ppm PEO; PEO200 means basal diet with 200 ppm PEO

${ }^{a}$ Values are means \pm S.E, $\mathrm{n}=6$

${ }^{\mathrm{b}}$ GSH glutathione, CAT catalase, $T$-AOC total antioxidant capacity, MDA methane dicarboxylic

and quadratically as PEO supplementation and $200 \mathrm{ppm}$ PEO supplementation obtained the best F:G. In agreement with our results, previous studies have documented similar positive effects of PEO supplementation on growth performance in weaned pigs $[17,24]$. The improvement in nutrient absorption may be partly explained by increased secretions of saliva, bile and enhanced enzyme activity [35-38].

Moreover, PEO supplementation has been reported to improve the immune status of pigs after weaning, as indicated by increased serum immunoglobulin levels $[15,17]$. Our results indicated that PEO supplementation increased the levels of ALB, IgA, and IgG in serum, and 200 ppm PEO addition got the highest levels. It is well known that IgG offers newborn pigs extended systemic protection, while IgA and IgM offer transient luminal protection [39]. During the first few days after weaning, piglets often experience low feed intake or starvation issues that can represent a major challenge for the producer. Therefore, the administration of $200 \mathrm{mg} / \mathrm{kg}$ PEO to piglets during this time probably improve their immune status and prevent oxidative stress.

Oxidative stress is caused by excess oxidative radicals, including reactive oxygen species (ROS) and reactive nitrogen species (RNS), which damage DNA, bio-membrane lipids, proteins, and other macromolecules [32]. However, excess oxidative radicals can be eliminated by antioxidants, including nonenzymatic components and a series of enzymes. Within the enzymatic antioxidant system, superoxide dismutase and glutathione peroxidase are the most important compounds [21], working together to detoxify superoxide anions and hydrogen peroxide in cells [33]. Superoxide dismutase catalyzes superoxide anions to produce hydrogen peroxide and molecular oxygen. Glutathione peroxidase normally converts $\mathrm{H}_{2} \mathrm{O}_{2}$ to water [21]. The capabilities of the non-enzymatic antioxidant defense system are often measured as the total antioxidant capacity [40]. Furthermore, the level of malondialdehyde, a major product of lipid peroxidation, is an effective marker of oxidative stress in sepsis [21].

In the present study, we measured GSH, CAT, MDA, and T-SOD levels, as well as T-AOC, in serum, intestinal mucosa, spleen, liver, and pancreas. Present results indicated that PEO supplementation significantly increased GSH levels in serum, duodenal and ileal mucosa and pancreas, T-SOD activity in jejunal mucosa and spleen, and significantly decreased MDA levels in serum, jejunal mucosa and pancreas. The results of this study were consistent with previous reports that T-AOC was improved and plasma MDA level was decreased in pigs receiving supplemental PEO [15, 41, 42]. Previous study have confirmed that PEO could save the depletion of 
Table 8 The levels of the gene expression of antioxidant enzymes in spleen, liver and pancreas of weaned pigs fed diets with different levels of PEO

\begin{tabular}{|c|c|c|c|c|c|c|}
\hline \multirow[t]{2}{*}{ Items $^{b}$} & \multirow[t]{2}{*}{ CON } & \multirow[t]{2}{*}{ PEO50 } & \multirow[t]{2}{*}{ PEO100 } & \multirow[t]{2}{*}{ PEO200 } & \multicolumn{2}{|l|}{ P } \\
\hline & & & & & Linear & Quadratic \\
\hline \multicolumn{7}{|l|}{ Spleen } \\
\hline$G R$ & $1.00 \pm 0.18$ & $0.79 \pm 0.11$ & $0.81 \pm 0.04$ & $1.12 \pm 0.16$ & 0.746 & 0.250 \\
\hline GST & $1.00 \pm 0.20$ & $1.11 \pm 0.25$ & $1.12 \pm 0.43$ & $2.92 \pm 0.42$ & 0.012 & 0.007 \\
\hline GPX1 & $1.00 \pm 0.21$ & $0.81 \pm 0.07$ & $0.75 \pm 0.07$ & $1.42 \pm 0.14$ & 0.236 & 0.029 \\
\hline$C A T$ & $1.00 \pm 0.15$ & $0.63 \pm 0.22$ & $0.86+0.11$ & $1.23 \pm 0.07$ & 0.366 & 0.051 \\
\hline SOD1 & $1.00 \pm 0.18$ & $0.76 \pm 0.08$ & $0.80 \pm 0.08$ & $1.31 \pm 0.08$ & 0.287 & 0.029 \\
\hline Nrf2 & $1.00 \pm 0.21$ & $0.94 \pm 0.11$ & $0.94 \pm 0.07$ & $1.13 \pm 0.12$ & 0.565 & 0.600 \\
\hline Keap1 & $1.00 \pm 0.13$ & $1.00 \pm 0.07$ & $1.04 \pm 0.14$ & $1.31 \pm 0.07$ & 0.085 & 0.129 \\
\hline \multicolumn{7}{|l|}{ Liver } \\
\hline$G R$ & $1.00 \pm 0.10$ & $1.08 \pm 0.27$ & $1.18 \pm 0.23$ & $0.90 \pm 0.15$ & 0.867 & 0.602 \\
\hline GST & $1.00 \pm 0.22$ & $0.71 \pm 0.03$ & $0.75 \pm 0.18$ & $1.16 \pm 0.37$ & 0.314 & 0.049 \\
\hline GPX1 & $1.00 \pm 0.35$ & $0.76 \pm 0.30$ & $0.94 \pm 0.36$ & $1.50 \pm 0.43$ & 0.421 & 0.456 \\
\hline CAT & $1.00 \pm 0.10$ & $0.84 \pm 0.19$ & $0.81 \pm 0.05$ & $1.28 \pm 0.14$ & 0.373 & 0.114 \\
\hline SOD1 & $1.00 \pm 0.13$ & $1.16 \pm 0.33$ & $1.01 \pm 0.15$ & $1.08 \pm 0.09$ & 0.865 & 0.956 \\
\hline Nrf2 & $1.00 \pm 0.07$ & $1.07 \pm 0.22$ & $0.75 \pm 0.27$ & $0.16 \pm 0.02$ & 0.023 & 0.029 \\
\hline Keap1 & $1.00 \pm 0.14$ & $0.86 \pm 0.17$ & $0.93 \pm 0.11$ & $0.80 \pm 0.11$ & 0.354 & 0.658 \\
\hline \multicolumn{7}{|l|}{ Pancreas } \\
\hline$G R$ & $1.00 \pm 0.07$ & $1.09 \pm 0.22$ & $1.15 \pm 0.11$ & $1.43 \pm 0.39$ & 0.342 & 0.628 \\
\hline GST & $1.00 \pm 0.31$ & $0.94 \pm 0.23$ & $0.93 \pm 0.24$ & $1.06 \pm 0.23$ & 0.935 & 0.957 \\
\hline GPX1 & $1.00 \pm 0.25$ & $0.88 \pm 0.04$ & $1.34 \pm 0.22$ & $1.19 \pm 0.27$ & 0.402 & 0.714 \\
\hline CAT & $1.00 \pm 0.19$ & $1.11 \pm 0.23$ & $1.07 \pm 0.18$ & $0.77 \pm 0.13$ & 0.502 & 0.569 \\
\hline SOD1 & $1.00 \pm 0.10$ & $0.66 \pm 0.09$ & $0.85 \pm 0.16$ & $1.03 \pm 0.13$ & 0.842 & 0.316 \\
\hline Nrf2 & $1.00 \pm 0.12$ & $0.91 \pm 0.16$ & $0.96 \pm 0.14$ & $0.95 \pm 0.19$ & 0.858 & 0.975 \\
\hline Keap1 & $1.00 \pm 0.21$ & $0.96 \pm 0.08$ & $1.24 \pm 0.18$ & $1.23 \pm 0.16$ & 0.326 & 0.629 \\
\hline
\end{tabular}

Treatments: CON means basal diet; PEO50 means basal diet with 50 ppm PEO; PEO100 means basal diet with 100 ppm PEO; PEO200 means basal diet with 200 ppm PEO avalues are means $\pm S . E, n=6$

${ }^{b} S O D 1$, superoxide dismutase 1; CAT, catalase; GPX1, glutathione peroxidase 1; GST, glutathione transferase; GR, glutathione reductase; Nrf2, nuclear factor E2-related factor 2; Keap-1, Kelch-like ECH-associated protein 1

SOD and GSH-Px or enhance their capabilities [21]. The increased GSH and decreased MDA levels in serum indicated that whole-body antioxidant status was improved, and lipid peroxidation was reduced. In addition, the reduced MDA levels and improvements in GSH levels and T-SOD activity suggested that PEO could enhance both the non-enzymatic and enzymatic reactions of the antioxidant defense system. Various natural antioxidant extracts have been used to protect pigs from weaning stress in intensive pig production [1]. Our results suggests that dietary PEO supplementation may reduce oxidative stress and have the potential to ameliorate the adverse effects of early weaning syndrome.

In order to elucidate the mechanism of PEO antioxidant activity in weaned pigs, we measured the expression of SOD1, CAT, GPX1, GST, GR, Nrf2, and Keap-1 in the spleen, liver, and pancreas. Keap-1 is the cytosolic protein with which the transcription factor $N r f 2$ is associated, and which functions to protect against oxidative stress. Oxidative stress modifies Keap-1 at redox-sensitive $\mathrm{SH}$ groups, leading to the liberation and nuclear translocation of $N r f 2$. Subsequently, Nrf2 binds to the ARE promoter sequence of antioxidant enzymes. In this way, $N r f 2$ coordinates cytoplasmic responses to oxidative stress [43]. A previous study reported that essential oils increased the mRNA expression of jejunal GPx1 and SOD1, ileal GST, and colonic GPX1, SOD1, and Keap-1 [44]. Similarly, the present results indicated that PEO supplementation upregulated the expression of GST, GPX, CAT, and SOD1 in the spleen and the expression of GST and Nrf2 in the liver. It can be speculated that the different terpene compounds in PEO can modify Keap 1 at sensor - $\mathrm{SH}$ groups through chemical reactions [45]. Oxidative stress modifies Keap1 at redox-sensitive - $\mathrm{SH}$ groups, which leads to Nrf2 liberation and its nuclear translocation. Subsequently, Nrf2 
binds to the ARE promoter sequence of antioxidant enzymes. In this way, Nrf2 coordinates cytoplasmic responses to oxidative stress [43]. The changes in the expression of genes associated with oxidation and antioxidant compounds may explain the findings in serum and tissue samples. The spleen is a vital part of the immune system and the liver is important in detoxification and metabolism in pigs [46, 47]. The improved splenic and hepatic antioxidant capacities may be reflected in the immunity and health of weaned pigs. Although the PEO used in our study has been confirmed to improve the antioxidant capacities of serum and other tissues, the molecular mechanisms through which PEO impacts the upstream $N r f 2$ pathways and then modulates antioxidant capacity remains to be further investigated.

\section{Conclusions}

In conclusion, our results suggest that dietary PEO supplementation improved growth performance, immune function, and antioxidant status in weaned pigs. The benefits observed may be mediated by upregulation of antioxidant-related genes in the spleen and liver. And that supplementation of the PEO preparation at the levels of $200 \mathrm{mg} / \mathrm{kg}$ diet would seem to be economically feasible. This study not only provides new insights into the role of PEO in improving growth performance, immune function, and antioxidant capacity in weaned pigs, but also reveals a potential candidate to replace the antibiotics conventionally used in the livestock industry.

\section{Abbreviations \\ ALB: Albumin; CAT: Catalase; GPX1: Glutathione peroxidase 1; GR: Glutathione reductase; GSH: Glutathione; GST: Glutathione transferase; Keap-1: Kelch-like ECH-associated protein 1; MDA: Methane dicarboxylic aldehyde; Nrf2: Nuclear factor E2-related factor 2; PEO: Plant essential oil; SOD1: Superoxide dismutase 1; T-AOC: Total antioxidant capacity; TP: Total protein; T-SOD: Total superoxide dismutase \\ Funding \\ This work was supported by the Special Fund for Agro-scientific Research in the Public Interest (201403047) and the Fok Ying Tung Education Foundation (141027).}

\section{Availability of data and materials}

The dataset supporting the conclusions of this article is included within the article.

\section{Authors' contributions}

$J H, D C, G C$ and $Y L$ were involved in the study design; XZ participated in data analysis, interpretation, $X Z$ and $Y W$ performed the animal management; GS drafted the manuscript. All authors read and approved the final manuscript.

\section{Ethics approval}

The animal experiment followed the actual law of animal protection and was approved by the Animal Care and Use Committee of the Sichuan Agricultural University and was performed in accordance with the National Research Council's Guide for the Care and Use of Laboratory Animals.

\section{Competing interests}

The authors declare that they have no competing interests.

\section{Publisher's Note}

Springer Nature remains neutral with regard to jurisdictional claims in published maps and institutional affiliations.

\section{Author details}

${ }^{1}$ Institute of Animal Nutrition, Sichuan Agricultural University, Chengdu, Sichuan 611130, People's Republic of China. ${ }^{2}$ Cheng Du Hua Luo Bio-Tech Col., Ltd, Chengdu, Sichuan 610062, People's Republic of China.

Received: 29 January 2018 Accepted: 23 May 2018

Published online: 15 June 2018

\section{References}

1. Zhu LH, Zhao KL, Chen XL, Xu JX. Impact of weaning and an antioxidant blend on intestinal barrier function and antioxidant status in pigs. J Anim Sci. 2012;90:2581.

2. Lallès JP, Boudry G, Favier C, NL F'H, Huêrou-Luron IL, Montagne L, Oswald IP, Pié S, Piel C, Sève B. Gut function and dysfunction in young pigs: physiology. Anim Res. 2004;53:301-16.

3. Pluske JR, Hampson DJ, Williams $\mathbb{H}$. Factors influencing the structure and function of the small intestine in the weaned pig: a review. Livest Prod Sci. 1997:51:215-36.

4. Wan J, Jiang F, Xu Q, Chen D, Yu B, Huang Z, He J. New insights into the role of chitosan oligosaccharide in enhancing growth performance, antioxidant capacity, immunity and intestinal development of weaned pigs. RSC Adv. 2017:7(16):9669-79.

5. Williams BA, Mwa V, Tamminga S. Fermentation in the large intestine of single-stomached animals and its relationship to animal health. Nutr Res Reviews. 2001;14:207-28.

6. Smith J, Tokach M, Goodband R, Nelssen J, Richert B. Effects of the interrelationship between zinc oxide and copper sulfate on growth performance of early-weaned pigs. J Anim Sci. 1997;75:1861-6.

7. Kim WK, Patterson PH. Effects of dietary zinc supplementation on broiler performance and nitrogen loss from manure. Poult Sci. 2004;83:34.

8. Hancock RE, Sahl HG. Antimicrobial and host-defense peptides as new antiinfective therapeutic strategies. Nat Biotechnol. 2006;24:1551-7.

9. Walsh AM, Sweeney T, O'Shea CJ, Doyle DN, O'Doherty JV. Effect of dietary laminarin and fucoidan on selected microbiota, intestinal morphology and immune status of the newly weaned pig. Br J Nutr. 2013;110:1630-8.

10. Smith AG, O'Doherty JV, Reilly P, Ryan MT, Bahar B, Sweeney T. The effects of laminarin derived from Laminaria digitata on measurements of gut health: selected bacterial populations, intestinal fermentation, mucin gene expression and cytokine gene expression in the pig. Br J Nutr. 2011;105:669-77.

11. Attia YA. Nigella seed oil as an alternative to antibiotic growth promoters for broiler chickens. Archiv Fur Geflugelkunde. 2015;79:1-12.

12. Attia YA, Bakhashwain AA, Bertu NK. Thyme oil (Thyme vulgaris L.) as a natural growth promoter for broiler chickens reared under hot climate. Ital J Anim Sci. 2017:16:275-82.

13. Franz C, Baser KHC, Windisch AW, Figueiredo AC, Miguel MG. Essential oils and aromatic plants in animal feeding - a European perspective. A review. Flav Fragr J. 2010;25:327-40.

14. Vardarunlü G, Candan F, Sökmen A, Daferera D, Polissiou M, Sökmen M, Dönmez E, Tepe B. Antimicrobial and antioxidant activity of the essential oil and methanol extracts of Thymus pectinatus Fisch. Et Mey. Var. pectinatus (Lamiaceae). J Agric Food Chem. 2003:51:63-7.

15. Zeng Z, Xu X, Zhang Q, Li P, Zhao P, Li Q, Liu J, Piao X. Effects of essential oil supplementation of a low-energy diet on performance, intestinal morphology and microflora, immune properties and antioxidant activities in weaned pigs. Anim Sci J. 2015;86:279-85.

16. Maenner K, Vahjen W, Simon O. Studies on the effects of essential-oil-based feed additives on performance, ileal nutrient digestibility, and selected bacterial groups in the gastrointestinal tract of piglets. J Anim Sci. 2011;89:2106-12.

17. Li SY, Ru YJ, Liu M, Xu B, Péron A, Shi XG. The effect of essential oils on performance, immunity and gut microbial population in weaner pigs. Livest Sci. 2012;145:119-23.

18. Zhang HY, Piao XS, Zhang Q, Li P, Yi JQ, Liu JD, Li QY, Wang GQ. The effects of Forsythia suspensa extract and berberine on growth performance, immunity, antioxidant activities, and intestinal microbiota in broilers under high stocking density. Poult Sci. 2013;92:1981-8.

19. Zeng Z, Zhang S, Wang H, Piao X. Essential oil and aromatic plants as feed additives in non-ruminant nutrition: a review. J Anim Sci Biotechnol. 2016;6:7. 
20. Zeng ZK, Li QY, Piao XS, Liu JD, Zhao PF, Xu X, Zhang S, Niu S. Forsythia suspensa extract attenuates corticosterone-induced growth inhibition, oxidative injury, and immune depression in broilers. Poult Sci. 2014;93:1774-81.

21. Lu T, Piao XL, Zhang Q, Wang D, Piao XS, Kim SW. Protective effects of Forsythia suspensa extract against oxidative stress induced by diquat in rats. Food Chem Toxicol. 2010;48:764-70.

22. Simitzis PE, Symeon GK, Charismiadou MA, Bizelis JA, Deligeorgis SG. The effects of dietary oregano oil supplementation on pig meat characteristics. Meat Sci. 2010;84:670.

23. Janz JA, Morel PC, Wilkinson BH, Purchas RW. Preliminary investigation of the effects of low-level dietary inclusion of fragrant essential oils and oleoresins on pig performance and pork quality. Meat Sci. 2007;75:350-5.

24. Li P, Piao X, Ru Y, Han X, Xue L, Zhang H. Effects of adding essential oil to the diet of weaned pigs on performance, nutrient utilization, immune response and intestinal health. Asian-Australas J Anim Sci. 2012;25:1617.

25. Manzanilla EG, Perez JF, Martin M, Kamel C, Baucells F, Gasa J. Effect of plant extracts and formic acid on the intestinal equilibrium of early-weaned pigs. J Anim Sci. 2004;82:3210-8.

26. USA, National Council. Nutrient requirements of swine. Nutr Requir Swine. 2012:44(3).

27. Fang T, Liu G, Cao W, Wu X, Jia G, Zhao H, Chen X, Wu C, Wang J. Spermine: new insights into the intestinal development and serum antioxidant status of suckling piglets. RSC Adv. 2016;6:31323-35.

28. Wei M, Wu Y, Chen D, Gu Y. Changes of free radicals and digestive enzymes in saliva in cases with deficiency in spleen-yin syndrome. J Biomed Res. 2010;24:250-5.

29. Zhu C, Hu W, Wu H, Hu X. No evident dose-response relationship between cellular ROS level and its cytotoxicity - a paradoxical issue in ROS-based cancer therapy. Sci Rep. 2014:4:5029.

30. Zhang JQ, Shen M, Zhu CC, Yu FX, Liu ZQ, Ally N, Sun SC, Li K, Liu HL. 3-Nitropropionic acid induces ovarian oxidative stress and impairs follicle in mouse. PLoS One. 2014;9:e86589.

31. Livak KJ, Schmittgen TD. Analysis of relative gene expression data using real-time quantitative PCR and the 2(-Delta Delta C(T)) method. Methods. 2001;25:402-8.

32. Zhao R, Shen GX. Functional modulation of antioxidant enzymes in vascular endothelial cells by glycated LDL. Atherosclerosis. 2005;179:277-84.

33. Zhang Q, Piao XL, Piao XS, Lu T, Wang D, Kim SW. Preventive effect of Coptis chinensis and berberine on intestinal injury in rats challenged with lipopolysaccharides. Food Chem Toxicol. 2011;49:61.

34. Placha I, Takacova J, Ryzner M, Cobanova K, Laukova A, Strompfova V, Venglovska K, Faix S. Effect of thyme essential oil and selenium on intestine integrity and antioxidant status of broilers. Br Poult Sci. 2014;55:105-14.

35. Jang IS, Ko YH, Yang HY, Ha JS, Kim JY, Kim JY, Kang SY, Yoo DH, Nam DS, Kim DH. Influence of essential oil components on growth performance and the functional activity of the pancreas and small intestine in broiler chickens. Asian-Australas J Anim Sci. 2004;17:394-400.

36. Lee KW, Everts H, Kappert HJ, Frehner M, Losa R, Beynen AC. Effects of dietary essential oil components on growth performance, digestive enzymes and lipid metabolism in female broiler chickens. Brit Poultry Sci. 2003;44:450-7.

37. Platel K, Srinivasan K. Influence of dietary spices and their active principles on pancreatic digestive enzymes in albino rats. Food. 2000;44:42-6.

38. Platel K, Srinivasan K. Stimulatory influence of select spices on bile secretion in rats. Nutr Res. 2000;20:1493-503.

39. Bureau FJ. Half-lives of immunoglobulins IgG, IgA and IgM in the serum of new-born pigs. Immunology. 1973;24:147.

40. Wang YZ, Xu CL, An ZH, Liu JX, Feng J. Effect of dietary bovine lactoferrin on performance and antioxidant status of piglets. Anim Feed Sci Technol. 2008;140:326-36.

41. Zhang HJ, Jiang XR, Mantovani G, Lumbreras AEV, Comi M, Alborali G, Savoini G, Dell'Orto V, Bontempo V. Modulation of plasma antioxidant activity in weaned piglets by plant polyphenols. Ital J Anim Sci. 2014;13:424-30.

42. Rossi R, Pastorelli G, Corino C. Application of KRL test to assess total antioxidant activity in pigs: sensitivity to dietary antioxidants. Res Vet Sci. 2013;94:372

43. Surh YJ. NF-kappa B and Nrf2 as potential chemopreventive targets of some anti-inflammatory and antioxidative phytonutrients with anti-inflammatory and antioxidative activities. Asia Pac J Clin Nutr. 2008;17(S1):269-72.
44. Mizumoto R, Kawarada Y. Effects of broccoli extract and various essential oils on intestinal and faecal microflora and on xenobiotic enzymes and the antioxidant system of piglets. Open J Anim Sci. 2012;2:78-98.

45. Hong F, Freeman ML, Liebler DC. Identification of sensor cysteines in human Keap1 modified by the cancer chemopreventive agent sulforaphane. Chem Res Toxicol. 2005;18:1917-26.

46. Eibl M. Immunological consequences of Splenectomy. Prog Pediatr Surg. 1985;18:139-45.

47. Desille M, Corcos L, L'Helgoualc'H A, Frémond B, Campion JP, Guillouzo A Clément B. Detoxifying activity in pig livers and hepatocytes intended for xenotherapy. Transplantation. 1999;68:1437-43.

\section{Ready to submit your research? Choose BMC and benefit from:}

- fast, convenient online submission

- thorough peer review by experienced researchers in your field

- rapid publication on acceptance

- support for research data, including large and complex data types

- gold Open Access which fosters wider collaboration and increased citations

- maximum visibility for your research: over $100 \mathrm{M}$ website views per year

At BMC, research is always in progress.

Learn more biomedcentral.com/submissions 